\title{
Identifikasi Kepadatan Larva Nyamuk Aedes Sp Sebagai Vektor Penyakit Demam Berdarah Dengue di Kelurahan Mogolaing Kotamobagu
}

\section{Identification of Aedes Sp Mosquito Larvae Density as a Vector of Dengue Hemorrhagic Fever in Mogolaing Village, Kotamobagu}

\author{
Annisa Aulia Cahyani Hulla ${ }^{1}$, Afdhal Khairu Ummah Anggol ${ }^{2}$, Hamzah B ${ }^{3}$, Hairil Akbar*4 \\ ${ }^{12}$ Mahasiswa Program Studi Kesehatan Masyarakat, STIKES Graha Medika, Kotamobagu \\ ${ }^{34}$ Dosen Program Studi Kesehatan Masyarakat, STIKES Graha Medika, Kotamobagu \\ e-mail: 1anisaauliacahyanih@gmail.com,2afdhal.anggol@gmail.com \\ 3hamzahbskm@gmail.com,*4 hairilakbar@stikesgrahamedika.ac.id
}

\begin{abstract}
Abstrak
Kasus demam berdarah dengue (DBD) di Indonesia pada tahun 2017 dilaporkan sebanyak 68,407 kasus dengan jumlah kasus meninggal sebanyak 493 orang dan IR 26,12. Provinsi Sulawesi Utara menempati urutan kedua yang memiliki CFR tinggi $(1,55 \%)$ setelah Gorontalo (2,18\%). Demam berdarah dengue (DBD) merupakan salah satu penyakit yang ditularkan oleh vektor nyamuk Aedes sp. Distribusi nyamuk Aedes sp dipengaruhi oleh perubahan lingkungan seperti ketinggian, suhu dan keadaan lingkungan. Masyarakat urban yang menggunakan tandon atau bejana sebagai tempat penampungan air yang tidak tertutup dapat meningkatkan populasi nyamuk Aedes sp menjadi tinggi. Jenis penelitian yang digunakan adalah penelitian yang bersifat deskriptif dengan jumlah sampel sebanyak 62 rumah yang ambil dengan teknik quota sampling. Data dikumpulkan menggunakan lembar observasi kemudian dianalisis secara deskriptif dan disajikan dalam bentuk tabel dan narasi. Hasil penelitian menunjukkan dari 115 rumah dan 516 yang diperiksa didapatkan 41 rumah dan 61 kontainer yang positif jentik Aedes sp dengan nilai House Index (HI) sebesar 35,65\%, kemudian dari 516 kontainer yang diperiksa didapatkan 61 kontainer yang positif jentik Aedes sp dengan Container Index $(\mathrm{Cl})$ sebesar $11,82 \%$, dan Bretau Index (BI) sebesar 53,04\%. Hasil perhitungan House Index (HI) menunjukkan angka 35,65\% dengan Desinty Figure (DF) adalah 5 yang menunjukkan kepadatan populasi larva di Kelurahan Mogolaing Kotamobagu masuk kedalam kategori sedang. Hal ini menunjukkan derajat penularan penyakit demam berdarah dengue (DBD) yang dibawa oleh vektor nyamuk Aedes sp adalah sedang sehingga perlu menjadi perhatian dan diwaspadai akan potensi kasus demam berdarah dengue (DBD) menjadi tinggi.
\end{abstract}

Kata kunci: Aedes sp, DBD, kepadatan, vektor

\begin{abstract}
Dengue hemorrhagic fever (DHF) cases in Indonesia in 2017 were reported as many as 68,407 cases with the number of cases died as many as 493 people and IR 26,12. North Sulawesi Province ranks second with a high CFR (1, 55\%) after Gorontalo (2, 18\%). Dengue hemorrhagic fever (DHF) is a disease transmitted by the mosquito vector Aedes sp. The distribution of Aedes sp mosquitoes is influenced by environmental changes such as altitude, temperature and environmental conditions. Urban communities that use reservoirs or vessels as uncovered water reservoirs can increase the population of Aedes sp. Mosquitoes to a high level. The type of research used is descriptive research with a total sample of 62 houses taken by quota sampling technique. Data were collected using observation sheets then analyzed descriptively and presented in tables and narration. The results showed that from 115 houses and 516 examined, 41 houses and 61 containers were positive for Aedes sp larvae with a House Index (HI) value of 35 , $65 \%$. From 516 containers examined, 61 positive containers Aedes sp. The Index (CI) is 11, 82\%, and the Bretau Index (BI) is 53 , 04\%. The results of the House Index (HI) calculation show a figure of $35.65 \%$ with a Destiny Figure (DF) of 5, which indicates that the population density of larvae in the Mogolaing Village Kotamobagu is in the medium category. This result shows that the degree of transmission of dengue hemorrhagic fever (DHF) carried by the Aedes sp mosquito vector is moderate, so it is necessary to pay attention and be aware of the potential for cases dengue hemorrhagic fever (DHF) to be high.
\end{abstract}

Keywords: Aedes sp, DHF, density, vectors

\section{Pendahuluan}

Menurut data WHO (2018) jumlah kasus DBD yang dilaporkan diketahui terjadi peningkatan jumlah kasus DBD dari 2,2 juta kasus pada tahun 2010 menjadi 3,2 juta kasus pada tahun 2015, sekitar $40 \%$ dari populasi dunia. Termasuk kasus yang tidak dilaporkan, WHO memperkirakan terdapat sekitar 50 juta-100 juta kasus DBD yang terjadi setiap tahunnya, terutama 
di Asia, Amerika Latin, dan Afrika. Pada tahun 2016, dilaporkan lebih dari 2,38 juta kasus terjadi di wilayah Amerika, 375.000 kasus dugaan di Wilayah Pasifik Barat, dan 1.061 kemungkinan kasus di Wilayah Afrika, Sementara di Indonesia, hingga tahun 2016, Kementerian Kesehatan Republik Indonesia mencatat angka kasus DBD mencapai 204.171 kasus dengan angka kematian sebesar 1.598 orang. Angka tersebut meningkat dari tahun sebelumnya di mana pada tahun 2015 tercatat sebanyak 129.650 kasus DBD dengan angka kematian sebesar 1.071 orang. ${ }^{1}$ Data WHO memperkirakan infeksi dengue terjadi 50 juta di seluruh dunia setiap tahun. Dilaporkan terjadi 500.000 kasus berkembang menjadi DBD yang menyebabkan 22.000 kematian sebagian besar pada anak-anak. $^{2}$ Dari tahun 1960 sampai dengan 2010, kasus DBD telah meningkat 30 kali lipat di seluruh dunia. ${ }^{3}$

Indonesia yang merupakan negara tropik yang secara umum mempunyai risiko terjangkit penyakit DBD, karena vektornya adalah nyamuk Aedes aegypti tersebar luas di kawasan pemukiman maupun tempat-tempat umum, kecuali wilayah yang terletak pada ketinggian lebih dari 1000 meter di atas permukaan laut. ${ }^{4}$ Menurut data dari Kementerian Kesehatan RI, pada tahun 2018 terdapat jumlah kasus DBD sebanyak 65.602 kasus dengan jumlahkematian sebanyak2.473 orang. Jumlah kasus DBD tahun 2018 meningkat dibandingkan jumlah kasus tahun 2017 (29.650 kasus). Jumlah kematian akibat DBD tahun 2017 juga meningkat dari tahun 2016 (1.071 kematian). IR atau angka kesakitan DBD tahun 2017 juga meningkat dari tahun 2016, yaitu 50,75 menjadi 78,85 per 100.000 penduduk. Namun, Case Fatality Rate (CFR) mengalami penurunan dari $0,83 \%$ pada tahun 2017 menjadi $0,70 \%$ pada tahun $2018 .^{5}$

Angka kematian atau CFR akibat DBD lebih dari 1\% dikatogorikan tinggi. walaupun secara umum CFR tahun 2017 menurun dibandingkan tahun sebelumnya. Provinsi Sulawesi Utara menempati urutan kedua yang memiliki CFR tinggi (1,55\%) setelah Gorontalo $(2,18 \%)$ dan Sulawesi Tenggara (1,47\%). Hal ini perlu diperlukan upaya pningkatan kualitas pelayanan kesehatan dan peningkatan pengetahuan masyarakat untuk segera memeriksakan diri ke sarana kesehatan jika gejala DBD sehingga tidak terlambat ditangani dan bahkan menyebab kematian. ${ }^{6}$

Kasus DBD di Sulawesi Utara menunjukkan angka yang berfluktuasi setiap tahunnya dan cenderung semakin meningkat angka kesakitannya. jumlah kasus tertinggi ada dikabupaten Minahasa Utara (329 kasus), kemudian diikut oleh Kota Manado (303 kasus) dan kabupaten Minahasa (260 kasus) sedangkan untuk kasus kematian tertinggi ada dikabupaten Minahasa (9 kasus kematian), diikuti Kota Manado, kabupaten Minahasa Utara, dan Kota Tomohon (masingmasing 3 kasus kematian). Tahun 2018 kasus DBD di Kotamobagu dilaporkan sebanyak 120 kasus. ${ }^{7}$

Manusia yang tertular penyakit DBD dikarenakan oleh gigitan nyamuk Aedes aegypti. Nyamuk Aedes aegypti dewasa berukuran lebih kecil jika dibandingkan dengan rata-rata nyamuk lain. Nyamuk ini mempunyai dasar hitam dengan bintikbintik putih pada bagian badan, kaki, dan sayapnya. Nyamuk Aedes aegypti jantan mengisap cairan tumbuhan atau sari bunga untuk keperluan hidupnya sedangkan yang betina mengisap darah. ${ }^{8}$ Beberapa faktor yang mempengaruhi terjadinya DBD adalah keberadaan jentik Aedes $s p$ dan faktor perilaku dari host itu sendiri. ${ }^{4}$ Distribusi nyamuk Aedes sp dipengaruhi oleh perubahan lingkungan seperti ketinggian, suhu dan keadaan lingkungan (Anwar). Keberadaan jentik di lingkungan rumah dipengaruhi oleh faktor fisik, biologi, kimia, dan perilaku. Faktor fisik antara lain keberadaan tanaman, dinding rumah yang rapat, keberadaan kontainer dan penutup kontainer, ketersediaan sumur gali, keberadaan tempat perindukan. ${ }^{9,10}$

Sebaran geografis Aedes sp di Asia Tenggara meliputi kawasan tropis dan subtropics, terletak di antara $40^{\circ} \mathrm{LU}$ dan $40^{\circ} \mathrm{LS}$ yang sesuai dengan isoterm $20^{\circ} \mathrm{C}$. Nyamuk ini terutama hidup di 
daerah urban (perkotaan) dan terkait dengan pembangunan penyediaan air dan meningkatnya sistem transportasi masyarakat di daerah urban yang menyediakan tandon air atau bejana (container) untuk menyimpan air cadangan sehingga populasi nyamuk ini selalu tinggi. ${ }^{11}$

Berdasarkan uraian diatas sehingga tujuan penelitian ini adalah untuk menganalisis kepadatan populasi nyamuk Aedes sp dengan menghitung parameter entomologi Container Index (CI), House Index (HI), Breteau Index (BI) dan Density Figure (DF) sebagai vektor penyebab demam berdarah dengue (DBD) di Kelurahan Mogolaing Kotamobagu.

\section{Metode Penelitian}

Jenis penelitian yang digunakan adalah penelitian yang bersifat deskriptif yang berfungsi untuk mendeskripsikan kepadatan populasi nyamuk Aedes sp dengan menghitung parameter entomologi Container Index (CI), House Index (HI), Breteau Index (BI) dan Density Figure (DF) sebagai vektor penyebab demam berdarah dengue (DBD). Lokasi penelitian di Kelurahan Mogolaing Kotamobagu dan waktu penelitian pada bulan Oktober 2020. Populasi pada penelitian ini adalah seluruh rumah penduduk disekitar kasus DBD di Kelurahan Mogolaing. Sampel penelitian diambil secara quota sampling yaitu sebanyak 62 rumah yang telah ditentukan disekitar rumah kasus DBD dalam radius 500 meter. Data dikumpulkan menggunakan lembar observasi kemudian dianalisis secara deskriptif dan disajikan dalam bentuk tabel dan narasi.

\section{Hasil}

Hasil penelitian pada tabel 1 menunjukkan jenis kontainer yang paling banyak di periksa adalah alas pot bunga sebanyak 121 dengan jumlah positif larva nyamuk Aedes sp sebanyak 23. Sedangkan jenis kontainer yang paling sedikit diperiksa adalah ban bekas sebanyak 26 dengan jumlah positif larva nyamuk Aedes sp sebanyak 3. Jenis kontainer yang paling sedikit terdapat positif larva jentik nyamuk Aedes sp.

Tabel 1. Jumlah Kontainer yang terdapat di Kelurahan Mogolaing Kotamobagu

\begin{tabular}{cccc}
\hline \multirow{2}{*}{ Jenis Kontainer } & \multicolumn{2}{c}{ Kelurahan Mogolaing } & Persentase \\
\cline { 2 - 3 } & Jumlah Kontainer & Positif Larva & Wadah $(\%)$ \\
\hline Tempayan & 67 & 1 & 12,98 \\
Bak Mandi & 60 & 8 & 11,62 \\
Bak Kakus & 58 & 3 & 11,24 \\
Drum & 50 & 5 & 9,68 \\
Ember Penampungan Air & 91 & 13 & 17,63 \\
Keleng Bekas & 43 & 5 & 8,33 \\
Ban Bekas & 26 & 3 & 5,03 \\
Alas Pot Bunga & 121 & 23 & 23,44 \\
\hline Total & 516 & 61 & 100 \\
\hline
\end{tabular}

Sumber : Data Primer 2021 
Tabel 2. Hasil Perhitungan House Index (HI), Container Index (CI), Bretau Index (BI) di Kelurahan Mogolaing

\begin{tabular}{cc}
\hline Komponen & Kelurahan Mogolaing \\
\hline Rumah yang diperiksa & 115 \\
Rumah positif & 41 \\
House Index $(\mathrm{HI})$ & $35,65 \%$ \\
Kontainer yang diperiksa & 516 \\
Kontainer positif & 61 \\
Container Index $(\mathrm{CI})$ & $11,82 \%$ \\
Bretau Index $(\mathrm{BI})$ & $53,04 \%$ \\
\hline
\end{tabular}

Sumber : Data Primer 2021

Hasil penelitian tabel 2 menunjukkan bahwa diperoleh dari 115 rumah yang diperiksa didapatkan 41 rumah yang positif jentik Aedes sp dengan nilai indeks House Index (HI) sebesar $35,65 \%$, kemudian dari 516 kontainer yang diperiksa didapatkan 61 kontainer yang positif jentik Aedes sp dengan Container Index (CI) sebesar 11,82\%, dan Bretau Index (BI) sebesar 53,04\%.

Tabel 3. Density Figure dan Nilai House Index (HI), Container Index (CI), Bretau Index (BI) di Kelurahan Mogolaing Kotamobagu

\begin{tabular}{ccccc}
\hline \multirow{2}{*}{ Kepadatan } & $\begin{array}{c}\text { Density Figure } \\
(\mathrm{DF})\end{array}$ & $\begin{array}{c}\text { House Index } \\
(\mathrm{HI})\end{array}$ & $\begin{array}{c}\text { Container Index } \\
(\mathrm{CI})\end{array}$ & $\begin{array}{c}\text { Bretau Index } \\
(\mathrm{BI})\end{array}$ \\
\hline Rendah & 1 & $1-3$ & $1-2$ & $1-4$ \\
\hline \multirow{3}{*}{ Sedang } & 2 & $4-7$ & $3-5$ & $5-9$ \\
& 3 & $8-17$ & $6-9$ & $10-19$ \\
& 4 & $18-29$ & $10-14$ & $20-34$ \\
\multirow{3}{*}{ Tinggi } & 5 & $29-37$ & $15-20$ & $35-49$ \\
\hline & 6 & $38-49$ & $21-27$ & $50-74$ \\
& 7 & $50-59$ & $28-31$ & $75-99$ \\
& 8 & $60-76$ & $32-40$ & $100-199$ \\
& 9 & $\geq 77$ & $\geq 41$ & $\geq 200$ \\
\hline
\end{tabular}

Sumber : Data Primer 2021

Hasil penelitian tabel 3 menunjukkan bahwa berdasarkan perhitungan Container Index (CI) dan House Index (HI) diperoleh angka 35,65\% dan 11,82\% yang menunjukkan angka Density Figure (DF) 4 dan 5, maka kepadatan populasi jentik nyamuk Aedes sp berada dalam kategori sedang, sedangkan hasil perhitungan Bretau Index (BI) diperoleh angka 53,04\% yang menunjukkan angka Density Figure (DF) 6, maka kepadatan populasi jentik nyamuk Aedes sp berada dalam kategori tinggi.

\section{Pembahasan}

Hasil penelitian menunjukkan bahwa jenis kontainer yang paling banyak terdapat positif larva nyamuk Aedes sp adalah alas pot bunga dan yang paling sedikit adalah jenis kontainer tempayan dengan jumlah positif larva sebanyak 1 . Hal ini dipengaruhi oleh keberadaan genangan air di alas pot bunga tidak menjadi perhatian masyarakat sehingga hal ini menjadi media yang bagus untuk nyamuk Aedes sp. Pada siang hari adalah waktu yang tepat untuk nyamuk Aedes sp aktif dan biasanya akan berbiak dan meletakkan telurnya pada genangan air atau tempat penampungan hujan. 
Sebuah tempat penampungan air, tempat untuk bunga seperti pot atau vas bunga, botol atau tabung dengan rongga yang sudah tidak terpakai yang memungkinkan air menggenang. ${ }^{12}$ Jenis kontainer kedua yang paling banyak terdapat larva jentik nyamuk adalah ember penampungan air dan bak mandi. Hal ini disebabkan oleh rata-rata seluruh kontianer dibiarkan terbuka dan sering menampung air dalam jumlah banyak oleh masyarakat sehingga hal ini menjadi tempat yang disukai oleh nyamuk Aedes sp untuk berkembang biak. Selain itu, masyarakat diketahui jarang dan lupa menguras air yang ada di bak mandi atau ember penampungan air, sehingga telur nyamuk Aedes $s p$ yang menempel di dinding kontainer dapat bekembang biak menjadi larva dan nyamuk dewasa. ${ }^{13}$

Lahirnya larva jentik nyamuk Aedes $s p$ di kontainer dalam rumah seperti bak mandi, bak kakus, drum, ember penampungan air karena masyarakat menguras air lebih dari 1 minggu sekali dan cara pengurasan air tidak tepat seperti tidak menyikat dinding kontainer sampai bersih sehingga telur yang menempel dapat melanjutkan siklus metamorfosisinya menjadi larva. ${ }^{14}$ Tempat penampungan air berpotensi untuk menjadian tempat perinduan nyamuk Aedes $s p$. Hal ini disebabkan karena tempat penampungan air yang tidak ditutup, lembab, terlindungi dari sinar matahari langsung dan nyamuk Aedes $s p$ bertelur pada air jernih, sehingga nyamuk dapat membuat siklus hidupnya pada tempat tersebut yaitu dari telur-jentik-pupa dan kemudian menjadi nyamuk dewasa. ${ }^{15}$

Kontainer yang berada di luar rumah berisiko terhadap keberadaan jentik karena mudah terjadi pembiakan nyamuk secara alami di kontainer. Pada penelitian ini didapatkan jenis kontainer yang positif larva jentik nyamuk Aedes $s p$ ban bekas, kaleng bekas, alas pot bunga. Nyamuk Aedes $s p$ dapat bertelur ditempat-tempat yang mempunyai volume air sedikit atau bahkan ditempat yang kering. ${ }^{16}$ Hasil penelitian yang telah dilakukan menemukan bahwa risiko keberadaan jentik adalah kontainer dengan sumber air PDAM dengan penyimpanan dengan bak, drum dan tempayan. ${ }^{17}$ Kondisi air responden yang jernih dan bersih dan tidak bersentuhan dengan tanah baik PDAM maupun air sumur gali sehingga banyak terdapat jentik Aedes sp. Hasil penelitian yang dilakukan di Perumahan Dinas Type E Desa Motu Kabupaten Mamuju Utara menemukan bahwa tempat penampungan air sangat mempengaruhi keberadaan jentik nyamuk $(\mathrm{p}=0,000)$, masyarakat yang membiarkan tempat penampungan air terbuka dapat menjadi tempat yang ideal untuk nyamuk berkembang biak. ${ }^{18}$

Pada tabel 2 menunjukkan nilai HI sebesar 35,65\%. Hal ini menunjukkan bahwa rumah yang positif larva di Kelurahan Mogolaing berisiko terjadinya penyakit yang ditransmisikan oleh nyamuk Aedes sp dikarenakan nilai HI melebihi dari standar yang ditetapkan WHO (House Index $\geq 10 \%$ ). House Index (HI) lebih menggambarkan luasnya penyebaran nyamuk disuatu wilayah. Jarak antar rumah mempengaruhi penyebaran nyamuk dari satu rumah kerumah lain, semakin dekat jarak suatu rumah maka semakin mudah nyamuk menyebar, Karena nyamuk Aedes sp dapat terbang 40-50 meter. ${ }^{19,20}$

Berdasarkan penelitian yang telah dilakukan menunjukkan KLB DBD di Jawa Tengah terjadi karena Angka Bebas Jentik (ABJ) yang masih dibawah standar 95\%, angka Counter Index (CI) didapatkan 11,84\% - 75,16 \%, angka House Index (HI) didapatkan 11,48\% - 75,86\% dan angka Bretau Index (BI) didapatkan 14,73-100 (20). House index (HI) merupakan indikator yang paling banyak digunakan untuk memonitor tingkat infestasi nyamuk. Nilai HI menggambarkan persentase rumah yang positif untuk perkembangbiakan vektor sehingga dapat mencerminkan jumlah populasi yang beresiko. ${ }^{21}$

Angka House Index (HI) akan menggambarkan luasnya penyebaran nyamuk disuatu daerah. Berdasarkan indikator HI (35,65\%), Kelurahan Mogolaing Kotamobagu termasuk risiko penularan sedang terhadap penyebaran penyakit DBD. Lingkungan sangat berhubungan dengan keberadaan 
larva Aedes sp misalnya kelembaban udara, keberadaan saluran air hujan yang kurang lancar dan keberadaan kontainer. Peningkatan curah hujan akan meningkatkan kelembaban dan temperatur yang mendukung seluruh aktivitas nyamuk termasuk memperpanjang umur dan perilaku nyamuk dalam melakukan reproduksi. Vektor Aedes $s p$ akan berkembang secara optimum pada temperatur 20-28 derajat Celcius. ${ }^{22}$

Tingginya kasus DBD di Kotamobagu terkait dengan kepadatan jentik nyamuk Aedes $s p$. Beberapa hal yang mempengaruhi kepadatan jentik nyamuk Aedes $s p$ adalah keberadaan container yang menjadi tempat berkembang biak nyamuk Aedes sp di lingkungan dalam rumah atau diluar rumah serta perilaku masyarakat membersihkan tempat penampungan air lebih dari satu minggu sekali. Pengendalian vektor dapat dilakukan dengan berbagai cara pembersihan sarang nyamuk (PSN) dengan cara mengurangi tempat perindukan, melakukan kegiatan 3M Plus, menguras tempat penampungan air secara teratur seminggu sekali, menutup tempat penampungan air, dan menyingkirkan barang-barang bekas yang dapat menampung air., pemberian larvisida, melakukan fogging dengan malathion di daerah wabah atau endemik, dan pendidikan kesehatan masyarakat agar memelihara lingkungan. Kegiatan yang berfokus untuk menurunkan populasi larva dengan kerja sama antar sektor dan masyarakat dianggap penting dalam usaha pengendalian vektor DBD agar membawa hasil yang maksimal. ${ }^{23}$

\section{Kesimpulan}

Berdasarkan hasil penelitian yang telah dilakukan hasil House Index (HI) menunjukkan angka 35,65\% dengan Desinty Figure (DF) adalah 5 yang menunjukkan kepadatan populasi larva di Kelurahan Mogolaing Kotamobagu masuk kedalam kategori sedang. Derajat penularan penyakit DBD yang dibawa oleh vektor nyamuk Aedes $s p$ adalah sedang sehingga perlu menjadi perhatian dan diwaspadai akan potensi kasus DBD menjadi tinggi.

\section{Saran}

Diharapkan kepada peneliti selanjutnya dalam melakukan penelitian yang terkait untuk menggunakan ovitrap dalam melihat kepadatan larva nyamuk Aedes sp, dan dapat melakukan survei larva pada saluran drainase masyarakat.

\section{Daftar Pustaka}

1. Rau SNMJ. 2021. Faktor yang Berhubungan dengan Keberadaan Jentik Nyamuk Aedes Aegepty di Wilayah Kerja Puskesmas Sangurara (Cross Sectional Study di Sulawesi Tengah, Kota Palu). MPPKI (Media Publ Promosi Kesehat Indones Indones J Heal Promot. 2021;4(2).

2. Sanyaolu A, Okorie C, Badaru O, Adetona K, Ahmed M, Akanbi O, et al. 2017. Global epidemiology of dengue hemorrhagic fever: an update. $J$ Hum Virol Retrovirol. 2017;5(6):179.

3. Hasan S, Jamdar SF, Alalowi M, Al Beaiji SMAA. 2016. Dengue virus: A global human threat: Review of literature. J Int Soc Prev Community Dent. 2016;6(1):1.

4. Fakhriadi R, Asnawati A. 2018. Analisis perbedaan faktor-faktor yang berpengaruh terhadap keberadaan jentik Aedes aegypti di kelurahan endemis dan kelurahan sporadis Kota Banjarbaru. JHECDs J Heal Epidemiol Commun Dis. 2018;4(1):31-6.

5. Awaluddin A. 2017. Korelasi Pengetahuan Dan Sikap Keluarga Terhadap Tindakan Pencegahan Demam Berdarah Dengue. J Endur. 2017;2(3):263.

6. $\quad$ Kemenkes RI. 2018. Infodatin: Situasi Penyakit Demam Berdarah di Indonesia Tahun 2017. 
Jakarta: Kementrian Kesehatan RI.

7. Dinkes Sulut. 2019. Profil Dinas Kesehatan Provinsi Sulawesi Utara Tahun 2018. Manado: Dinas Kesehatan Sulawesi Utara.

8. Akbar H, Maulana Syaputra E. Faktor Risiko Kejadian Demam Berdarah Dengue (DBD) di Kabupaten Indramayu. MPPKI (Media Publ Promosi Kesehat Indones Indones J Heal Promot. 2019;2(3):159-64.

9. Ayun LL. 2017. Hubungan Antara Faktor Lingkungan Fisik dan Perilaku Dengan Kejadian Demam Berdarah Dengue (DBD) di Wilayah Kerja Puskesmas Sekaran, Kecamatan Gunungpati, Kota Semarang Tahun 2015. Public Heal Perspect J. 2017;2(1).

10. Fakhriadi R, Yulidasari F, Setyaningrum R. 2015. Faktor Risiko Penyakit Demam Berdarah Dengue di Wilayah Kerja Puskesmas Guntung Payung Kota Banjarbaru (Tinjauan Terhadap Faktor Manusia, Lingkungan, dan Keberadaan Jentik). J Publ Kesehat Masy Indones. 2015;2(1).

11. Soekiman S. 2012. Demam Berdarah Dengue-Dengue Haemorrhagic Fever. Jakarta: Sagung Seto.

12. Muda AS. 2019. Determinan Yang Berhubungan Dengan Keberadaan Jentik Di Kelurahan Rangkah Buntu, Surabaya. J PROMKES. 2019;7(1):22.

13. Sunaryo S, Pramestuti N. 2014. Surveilans Aedes aegypti di daerah endemis demam berdarah dengue. Kesmas Natl Public Heal J. 2014;8(8):423-9.

14. Ichwani R. 2018. Kepadatan Larva Nyamuk Aedes spp Sebagai Vektor Penyebab Demam Berdarah Dengue (DBD) di Daerah Pesisir Alue Naga Kecamatan Syiah Kuala Banda Aceh. J Ilm Mhs Vet. 2018;2(4):488-92.

15. Nardin N, Fa'al Santri N, Ashafil R. 2019. Identifikasi Jentik Nyamuk Aedes Aegypti Pada Bak Mandi di Toilet Kampus $\mathrm{V}$ Universitas Indonesia Timur. I Media Laboran. 2019;9(2):13-7.

16. Kemenkes RI. 2013. Pedoman pengendalian demam berdarah dengue di Indonesia. Jakarta: Kementrian Kesehatan RI.

17. Azizah FN, Hermawati E, Susanna D. 2018. Menguras dan Menutup sebagai Prediktor Keberadaan Jentik pada Kontainer Air di Rumah. Ber Kedokt Masy. 2018;34(6):242-7.

18. Gafur A, Saleh M. Hubungan Tempat Penampungan Air dengan Keberadaan Jentik Aedes aegypti di Perumahan Dinas Type E Desa Motu Kecamatan Baras Kabupaten Mamuju Utara. Hig J Kesehat Lingkung. 2015;1(2):93-9.

19. Ramadhani TA. 2011. Analisis Timbulan dan Komposisi Sampah Rumah Tangga di Kelurahan Mekar Jaya (Depok) Dihubungkan dengan Tingkat Pendapatan, Pendidikan, Pengetahuan, Sikap Perilaku Masyarakat. Skripsi Jur Tek Lingkungan, Univ Indones Depok.

20. Widiarti W, Setiyaningsih R, Pratamawati DA. 2018. Implementasi Pengendalian Vektor DBD di Provinsi Jawa Tengah. J Ekol Kesehat. 2018;17(1):20-30.

21. Khairunnisa U, Wahyuningsih NE, Hapsari H. 2017. Kepadatan Jentik Nyamuk Aedes sp.(House Index) sebagai Indikator Surveilans Vektor Demam Berdarah Dengue di Kota Semarang. J Kesehat Masy. 2017;5(5):906-10.

22. Widjajanti W, Ayuningtyas RTD, Adnyana NWD. 2019. Indeks Entomologi Vektor Demam Berdarah Dengue di Tiga Kabupaten Di Provinsi Bali. Vektora J Vektor dan Reserv Penyakit. 2019;11(1):11-20.

23. Lomi AC, Martini M, Santoso L. 2015. Hubungan Kepadatan Vektor dengan kejadian DBD di Kelurahan Bandarharjo Kota Semarang. J Kesehat Masy. 2015;3(1):121-6. 